Исидора Г. Бјелаковић*

\title{
НАПОМЕНЕ О МОРФОЛОШКОЈ СТРУКТУРИ ДОКУМЕНАТА АРХИВА МАНАСТИРА САВИНА (18. ВЕК) ${ }^{* *}$
}

У раду се анализира морфолошка структура докумената који се чувају у Архиву манастира Савина, а написани су у 18. веку - у манастиру или у околним областима које припадају источнохерцеговачком дијалекатском простору. Истраживање се реализује како би се применом тзв. статистичке методе описала морфолошка структура анализираних текстова, те уочило време продирања књишких (рускословенских) карактеристика. Посебна пажња посвећена је појединим регионалним цртама, карактеристичним за говоре северозападне Боке и ширег подручја источне Херцеговине.

Кључне речи: Архив манастира Савина, 18. век, морфолошка структура, српски језик.

\section{1. УВОД}

Иако су досадашња истраживања писаних језика̂ Срба у 18. веку у великој мери поставила основну хронологију појаве и смене појединих књижевнојезичких идиома, она се пре свега везују за територију некадашње Јужне Угарске и текстове књижевноуметничког, научног и публицистичког профила (нпр. Албин, 1968; Kuna, 1970; Младеновић, 1964; Херити, 1983; и др.). С друге стране, анализе језика српских текстова административног карактера 18. века, иако се не односе само на области некадашње Јужне Угарске, због своје фрагментарне природе још увек не могу да пруже потпуну слику о употреби, коегзистенцији и конкуренцији језичких идиома у њима (в. Младеновић, 1972; 1973; 1977; 1987; 1992; Стојановић, 2011а; 2011б; 2012; и др.).

\footnotetext{
*isidora.bjelakovic@gmail.com

** Овај рад представља резултат истраживања у оквиру пројекта Историја српског језика (178001) Министарства просвете, науке и технолошког развоја Републике Србије.
} 
У србистици су, дакле, још увек отворена следећа питања: (1) питање идентитета језика̂ који су егзистирали у пословно-правним текстовима 18. века на ширем штокавском подручју, (2) утврђивање јаснијих хронолошких граница у погледу појаве књишких (рускословенских) наноса и губљења српскословенског.

\section{2. ПРЕДМЕТ, КОРПУС И ЗАДАЦИ ИСТРАЖИВАЬА}

2.1. Узимајући све наведено у обзир, фокус овог истраживања постављен је на анализу морфолошке структуре језика докумената пословно-правног карактера из 18. века, чуваних у Архиву манастира Савина. ${ }^{1}$ Током анализе примењена је тзв. метода упитника, ${ }^{2}$ у извесном смислу модификована, будући да добијени резултати нису статистички обрађени. Поред тога, регистровано стање упоређено је са језиком писама владике Данила (према Младеновић, 1973). ${ }^{3}$

Будући да су говори северозападне Боке (где се и налази ман. Савина) на крајњем југоистоку источнохерцеговачког дијалекатског простора, посебна пажња посвећена је и појединим регионалним цртама, карактеристичним за савремене говоре како овог региона тако и ширег подручја источне Херцеговине (према Пецо, 1964; Вујадиновић, 2007). Из тог разлога анализирани су само они документи који су писани у манастиру или у околини, а који припадају источнохерцеговачком дијалекту.

\footnotetext{
${ }^{1}$ Више о фонолошким особеностима језика истих докумената в. у Бјелаковић, 2018.

2 Статистичка метода (или метода упитника) подразумева регистровање и анализу односа дистинктивних језичких црта рускословенског, руског књижевног, српског народног, па и српскословенског језика у једном тексту. Наведени модел уведен је у науку 1964. г. (в. Младеновић, 1964) и временом се разрађивао у монографским описима и радовима како проф. Младеновића тако и многобројних историчара језика (в. Младеновић, 1969; Албин, 1968; Кашић, 1968; Јерковић, 1972; 1976; Херити, 1983; Суботић, 1989; Милановић, 2014; Нуорлуото, 2017; и др.). Више о овој методи в. у Суботић, 2004.

3 У питању је анализа писама владике Данила у периоду 1700-1734. (в. Младеновић, 1973: 6).
} 
2.2. Корпус за анализу представљали су следећи текстови: ${ }^{4}$

У 1704, 12. 8. (Топла): Уговор о залогу земље на Ђурђевом брду Костадина, Комлена и Јова, синова кнеза Драгутина Ђурђевића (пореклом из околине Требиња), Јовану Војновићу са Савине. Писмо саставио Продан Магазиновић, пореклом из околине Требиња;

П 1709, 14. 10. (Топла): Потврда о исплаћеном дугу за баштине на Ђурђевом брду кнеза Јована;

У 1714, 1. 9. (Савина): Уговор Петка Терзића са Савине и проигумана савинског оца Гаврила. Писао кнез Продан Магазиновић;

П 1715, 20. 3. (Рисан): Потврда Михаила Јованова и Јова Шћепанова да су од капетана Петра Ћеловића из Рисна примили новац. Потврду је исписао Мато Вуков;

П 1747, 3. 6. (Нови): Потврда о позајмици новца Пијетра Фонтане од игумана савинског Арсенија Милутиновића (Нови). Потврду је саставио Пијетро Фонтана, преводилац за илирски језик;

ПИ 1749, 6. 8. (Савина): Писмо игумана ман. Савине Арсенија Милутиновића савинском и општинском заступнику Марку Мирковићу са Топле поводом обнове приморске епископије;

ПИ 1750, 10. 8. (Савина): Писмо Арсенија, игумана ман. Савине, манастирском и општинском заступнику у Млецима Марку Марковићу поводом активности приликом избора далматинског архијереја;

О 1751, 11. 1. (Савина): Опорука Ђура Станића из Савине (непознат састављач; могуће је да је тестамент диктирао Ђуро Савић јер је писана у првом лицу);

О 1757, 20. 4. (Савина): Опорука оца Луке Лучића (највероватније из Сушћепана или Савине), сабрата манастира Савина. Опоруку је исписао отац Димитрије Владојевић са Пода, а оверио ју је игуман ман. Савина Софроније Видаковић из Требесиња;

П 1763, 29. 11. (Нови): Потврда о измирењу квитанције Јова Радоњића, са Пода, кмета ман. Савине. Потврду саставио Нико Комленовић;

\footnotetext{
${ }^{4}$ Називи докумената и подаци о ауторима наведени су према публикацији Г. Комара Ћирилски споменици 17. 18. и 19. вијека (ActaSerbica) (2009). Анализа је спроведена на основу снимака оригинала које је г. Комар уступио за потребе пројекта Речник српског језика XII-XVIII века Матице српске.
} 
П 1773, 16. 11. (Савина): Пуномоћ и потврда о боравку оца Инокентија Дабовића, сабрата ман. Савина, за пут у Угарску. Пуномоћ саставили капетани и суђе из комунитади Топла;

О 1775, 26. 1. (Савина): Објава о делегирању архимандрита Данила Рајовића и јеромонаха Никанора Богетића у Млетке ради потраживања новца за изградњу цркве. Објаву потврдили чланови братства ман. Савина. Непознат састављач;

П 1778, 2. 9. (Савина): Копија потврде прокураторима о преузимању имања која је покојни Симо Милутинов Томашевић Магазиновић тестаментарно оставио манастиру Савина. Писмо саставио Данил Рајовић, архимандрит ман. Савина;

П 1779, 6. 3. (Нови): Попис робе у дућану Мојсија Магазиновића и Јова Косанчића.

Као контролни корпус приликом анализе послужило је и 6 издатих докумената (в. Комар, 2009), такође из Архива манастира Савина, чији оригинали нису били доступни:

У 1725, 5. 3. (Топла): Уговор Драгутина и Ника Магазиновића и ман. Савине. Састављач је игуман ман. Савине Арсеније Милутинов Калуђеровић;

ПИ 1725, 21. 8. (Савина): Писмо савинског архимандрита Леонтија Рајовића Пијетру Фонтани;

О 1731, 30. 8. (Сушћепан): Опорука Горде Маринковић. Текст записао поп Никола Аврамовић из Требесиња;

П1 1747, 4. 4. (Млеци): Писмо Марка Мирковића оцу Арсенију, савинском игуману;

П2 1747, 20. 12. (Млеци): Писмо Марка Мирковића оцу Арсенију, савинском игуману;

И 1773, 14. 4. (Савина): Извештај о имовини манастира Савина јеромонаха Софронија Видаковића из Требесиња.

\section{3. АНАЛИЗА}

\section{1. Именичка промена}

3.1.1. Генитив једнине именица женског рода на -а. У анализираним документима доследно се употребљава народни наставак -e: нека-се зна п-овоме писму али-ти шкриту како узе иа петко терзићъ савине у господина 
проигумна гаврила калућера савине на-бутигу цекина $35 \ldots$ (У 1714, 1. 9); ${ }^{5}$ за године три $(1714,1.9)$; о-д-руге руке двије (П 1715); ...од геа аршениа игумна манастира савине ове државе (П 1747, 3. 6); три године (П 1747, 3. 6); шд-наше Потребне Церкве Свете госпоће (ПИ 1749); три године (ПИ 1749); Фт-наше убоге церкве (ПИ 1750); ћуро симовъ станић савине (О 1751); од-цркве свете госпоће (О 1751); код церкве (1757); код церкве свете госпоће (1757); сваке године (1757); шдъ-савине (П 1763); Фд Топле-државе новске (П 1773); по закону сте Матере цркве восточне јеросалимске (П 1773); двїе бутиге (П 1778); код-ове Церкве СТе Госпоже $\overline{\text { พ}-с а в и н е ~(П ~ 1778) ; ~ о д ъ ~ к н и г е ~(О ~ 1779) ~ и ~}$ др. ${ }^{6}$

3.1.2. Датив и локатив једнине именица женског рода на -а. Наставак -u, специфичан за српски језик, доминантан је у анализираној грађи: у-Фвой церкви (ПИ 1749); оставлам моиюи жени-мари и моиюи невиести анћи (О 1751); иани-сестри за душу (О 1751); у монастиру Саввїни (1757); на служби (1757); препоручуе [...] и престой дъви-марїи (1757); у дружби другога Сщеника (О 1775); На-савини (П 1778); у бутизи (П 1778; П 1799).

Ретки примери књишког наставка -еl-ь (в. Ремнёва и др., 1999: 43) бележе се, уз оне на народном, од средине 18. века. Увек је реч о именици којом се именује манастир и/или о есхатоколу (крају писма): на савине (ПИ 1750); ва купе (ПИ 1750); Дато во С Тоуспенскомъ Мона ${ }^{\mathrm{c}}$ тирь Савинъ (П 1778; есхатокол).

3.1.3. Инструментал једнине именица женског рода на -а или на -ф. Посведочени примери указују на готово доследну употребу народног наставка -ом: по[д] кућомъ попа ћура (У 1714, 1. 9); с-ваидом без икаква инада (П 1747 , 3. 6); тако да-ие она власница моишм кућомъ и землом колико и с-моишм душом (О 1751); с-нашомъ заклетвомъ (П 1773); и др.

Само је у једном примеру забележен књишки наставак -еју (в. Ремнёва и др., 1999: 49). Опет је реч о лексеми сакралне тематске области: 3-братїею (П 1778).

\footnotetext{
${ }^{5}$ У наведеним примерима реч је о хаплографији (савине $\rightarrow$ са Савине).

6 Забележено стање одговара ситуацији у језику владике Данила (Младеновић, 1973: $125)$.
} 
Именица женског рода на анализираној грађи само у једном примеру, са књишким наставком -ију (в. Ремнёва и др., 1999: 50): с-користїю (ПИ 1749). ${ }^{7}$

3.1.4. Локатив једнине именица мушког и средњег рода. У локативу једнине именица мушког и средњег рода готово се доследно употребљава народни наставак $-y:^{8}$ Нека се зна п-о-вому писму... (У 1704, 12. 8); ...що се наоди на ћурћеву брду (У 1704, 12. 8); на први сетемра [...] 1714 у новому (У $1714,1.9 ; 1757)$; на истомъ винограду (У 1714, 1. 9); на свакоме месту (У $1714,1.9) ;$ у Рисну (П 1715); у монастиру (ПИ 1750); у монастиру Саввїни (1757); по начину (1757); у-овоме нашему Манастиру (П 1773); у мотиру (О 1775); у-монастиру (П 1778); у либру (П 1778).

Посведочен је само један пример са књишким наставком (в. Ремнёва и др., 1999: 48). Реч је, такође, о есхатоколу: Дато во Стоуспенскомъ Мона Савинъ (П 1778).

3.1.5. Номинатив и акузатив множине именица женског рода на -а. Анализирана грађа указује на доследну употребу народног наставка -e: узе у мое руке іа исти петко терзић (У 1714, 1. 9); що сте у-ваше руке примили (ПИ 1749); ... да-су доне и мадоне

3.1.6. Генитив множине именица сва три рода. У највећем броју примера употребљава се народни наставак - $a$, што одговара стању у савременим говорима источне Херцеговине (в. Пецо, 1964: 118, 120, 124): а пак узе сувише свр овие цекина (У 1714, 1. 9); примихь иа $[. .$.$] дуката биелие$ 20 ... (П 1715); три године дана (П 1747); под облег моие добара (1747); Цекина Петнаестъ (ПИ 1749); ...дазаиного Познати не-хоћемо и отъ инїехъ монастира точїю однашего монастира (ПИ 1750); више од година 30 (1757); како-е примию у-частние отаца (П 1763). ${ }^{10}$

${ }^{7}$ Слична ситуација регистрована је и у језику владике Данила (Младеновић, 1973: 126).

${ }^{8}$ Слична је ситуација и у језику владике Данила (Младеновић, 1973: 126).

${ }^{9}$ На овакву употребу указују и примери посведочени у језику писама владике Данила (Младеновић, 1973: 127).

10 У језику владике Данила ови наставци нису регистровани. Употребљавају се само $a x,-u x,-\phi,-о в$ (Младеновић, 1973: 128). 
У двама примерима регистрован је наставак -ax: и удержати такве праведне узроке нашиехъ сщеникахъ (О 1775); мирно владанъ земаляхъ (О 1775). ${ }^{11}$

Као што и претходни примери показују, финалне консонантске групе основе доследно се разбијају: Знамъ да-имате [...] вашиехъ Посала (ПИ 1749); Фд-истие банада (П 1763).

3.1.7. Акузатив множине именица мушког рода. У акузативу множине именица мушког рода забележена је доследна употреба народног наставка -e: донесите-ми собомъ динаре (ПИ 1749); и удержати такве праведне узроке (О $1775)$; шбћено за више речене после (О 1775); и др.

3.1.8. Датив, инструментал и локатив множине именица. Иако је у грађи забележен релативно ограничен број потврда именица у овим падежима, уочава се следећа ситуација:

а. Док се у дативу множине именица старе - $a$ промене региструје употреба наставка -ам (истина-е да-сте Писали Свїетлому геуу Капетанъ Вуковою инеговїемъ Сућамъ, вашиемъ Колегамъ... - ПИ 1749), ${ }^{12}$ дотле се у инструменталу множине уочавају наставци -ама (под скалама - П 1778) и ами - уз именицу сакралне тематике и/или крај писма: со-братїями (ПИ 1749; 1750; есхатокол, потпис); 3-братїами (П 1778). ${ }^{13}$

б. У дативу, инструменталу и локативу множине именица мушког рода регистрована је доследна употреба наставка -има: у-млецима (ПИ 1749); с-онїемъ начинима (ПИ 1749); са-свїемъ госпоцкїемъ законима (П 1778); сниовїемъ рафима (П 1778); ...да-му-се На-сваку Годину, На-пресвьтои Служби Божїеи, Сарандарима Поминаютъ, имена, коя-се именуют у-овому писму (П 1778); у комадима (П 1779). ${ }^{14}$

11 у језику владике Данила овај је наставак регистрован у далеко већем броју случајева (Младеновић, 1973: 128-129).

12 Овај се наставак, поред општераспрострањеног -ама, у дативу множине у савременим говорима источне Херцеговине најчешће региструје код Муслимана (Пецо, 1964).

${ }^{13} \mathrm{У}$ контролном корпусу забележена је, такође, форма на -ами: с нашијем руками (У 1725).

14 Контролни корпус бележи и пример именица у дативу множине: дужни оцима и калођерима (У 1725). У савременим говорима источне Херцеговине и у Каменарима ово је, такође, најчешћи наставак (Пецо, 1964: 120; Вујадиновић, 2007: 80, 81). 
Анализирана грађа указује, дакле, на то да је у мушком роду у потпуности стабилизован наставак -има за сва три падежа, ${ }^{15}$ док се код именица женског рода у дативу чува - $a$, а у инструменталу -ама и -ами (само уз форму братија).

3.1.9. Очекивано, грађа указује на доследну употребу хипокористика мушких имена на -о, чија деклинација одговара промени именица мушког рода на консонант: ${ }^{16}$ Июво $(У ~ 1704,12.8)$; иа кнезъ проданъ магазиновић ово писа - бих моленъ од сва три-брата костадина комлена иова (У 1704, 12. 8); по[д] кућомъ попа ћура (У 1714, 1. 9); мато вуковъ (О 1715); од-истога михаила иова (П 1715); ћуро симовъ станић (О 1751); Фд июва радонића (П 1763).

\section{2. Заменичко-придевска промена}

3.2.1. У генитиву једнине мушког и средњег рода, као и у акузативу једнине мушког рода најчешће се срећу народни наставци -ога/-ега: одъ реченога петка терзића (У 1714); од-истога михаила иова (П 1715); на-конат горнега писма (П 1747); у преведрога Принципа (ПИ 1749); милос имати пастира нашега, што ... (ПИ 1749); по-заповїеди вашой и-вашега Писма (ПИ 1749); ... да-су доне и мадоне ё-свега-мога сиромащва (О 1751); истога Луке (1757); на служби преузвишенога принципа (1757); половина реченога (1757); Фд июва радонића кмета истога монастира (П 1763); питанђ вишереченнога оца (П 1773); з-допуштенъмъ свога вишереченога манастира (П 1773); у дружби другога Сщеника (О 1775); до владаня Мнетачкога (О 1775); зачетвертога Прокаратора (П 1778). ${ }^{17}$

Књишки наставци регистровани су од средине 18. века и везују се за образовања у оквиру синтагми које реферишу о религиозном контексту, о представницима високе црквене хијерархије, о устаљеној етикецији и формулацијама приликом завршавања писама: Много времена има да нїесамъ Примию-вашего Писанїя... (ПИ 1749); вашего добра желатель (ПИ 1749;

\footnotetext{
15 За разлику од ове ситуације, у језику једног писма из Зубаца из 1728. г. забележен је и наставак -ом у дативу множине именице граничник (граничником) (Младеновић, 1977: 279).

${ }^{16}$ Иста ситуација потврђена је и у савременим говорима источне Херцеговине (Пецо, 1964: 129) и Каменара (Вујадиновић, 2007: 80).

17 У језику писама владике Данила забележена је слична ситуација (Младеновић, 1973: 145-146).
} 
есхатокол); При-сем-же шстаю-се вашегФ Благородїя усерднїи добра желатель, и богомоляць Арсеній Игуменъ (ПИ 1750; есхатокол); $\mathbb{w}$-вашего Благородїя (ПИ 1750); ऊ̄ пречестньишаго [...] оца 1775); и сл.

Интересантно је и писмо из 1750 , у којем се уз исту именицу једном употребљава књишка, а други пут народна форма: ... точїю од-нашего монастира (ПИ 1750), Фд-нашега монастира (ПИ 1750).

3.2.2. У генитиву једнине заменичко-придевске промене женског рода употребљава се, готово доследно, народни наставак -е, без обзира на тематику и контекст: о-д-руге руке двије (П 1715); ...од гна аршениа игумна манастира савине ове државе (П 1747, 3. 6); Фд-наше-Потребне Церкве Свете госпоће (ПИ 1749); Фт-наше-убоге церкве (ПИ 1750); ћуро симовъ станић савине наюдећи-се у постели болан ма ума добра и риечи здраве (О 1751); од цркве свете госпоће (О 1751); код церкве свете госпоће (1757); сваке године (1757); Фд Топле државе новске (П 1773); по закону $\underline{\text { сте }}$ Матере цркве восточнејеросалимске (П 1773).

Само је једном потврђен књишки (рускословенски) наставак -ија (в. Ремнёва и др., 1999: 54): и за помоћь Новїя Церкве (П 1778).

3.2.3. У инструменталу једнине средњег рода бележи се само наставак -ијем: с-овиемъ истинитием писмом (О 1751). У формама женског рода наставак је -ом: тако да-ие она власница моиюм кућомъ (О 1751); с-нашомъ заклетвомъ (П 1773); и др.

3.2.4. У дативу/локативу једнине мушког и средњег рода бележе се наставци -оме и -ом: ... на свакоме месту (У 1714); на истомъ винограду (У 1714); а у женском роду -ој: Топлои (1704); по-заповїеди вашой (ПИ 1749); По своїои воли (ПИ 1750); препоручуем моиу душу [...] пресветои матери ристовои (О 1751); оставлам моиюи жени мари и моиюи невиести анћи (О 1751); у-малои бутизи (П 1778).

Књишки наставак регистрован је само у једном примеру, тематски везаном за сферу религије: ...да-му-се На-сваку Годину, На-пресвђтои Служби Божїеи, Сарандарима Поминаютъ, имена, коя-се именуют у-овому писму (П 1778).

3.2.5. У генитиву множине мушког и средњег рода забележени су наставци -ије (најчешће) и -ијех (једном): а пак узе сувише свр овие цекина (У $1714,1.9)$; под облег моие добара $(1747,3.6)$; од-истога михаила иова озгаръ зазватие (П 1715); да-се ивормате у-онїе у-коие ви знате (ПИ 1749); како-е примию у-частние отаца (П 1763); кога-су-били послали како брата Фд-истога 
манастира у церку прошлїе годища (П 1773); и удержати такве праведне узроке нашиехъ сщеникахъ (О 1775).

3.2.6. У акузативу множине мушког и женског рода забележен је само народни наставак -e: ...а-речене цекине да-му-и имамъ лиепо вратити (У 1714 , 1. 9); изповиедам іа подписани како примих у мое руке (П 1747, 3. 6); наредити ныгове-мале ствари (1757); и удержати такве-праведне узроке (О 1775); шбћено за више речене после (О 1775).

3.2.7. У инструменталу множине мушког рода регистрован је наставак -ијем: с-онїемъ начинима с-коиемъ пристои (ПИ 1749).

3.2.8. У инструменталу једнине, генитиву, дативу, инструменталу и локативу множине уопштавају се, дакле, некадашњи наставци тврде заменичке промене, што одговара стању у говорима источне Херцеговине (Пецо, 1964: 137) и Каменара (Вујадиновић, 2007: 86-87). ${ }^{18}$

\section{3. Компаратив и суперлатив}

Књишке суперлативне форме (в. Ремнёва и др., 1999: 58-62) уочавају се, очекивано, уз имена црквених великодостојника и угледних званичника (нпр. часнђиши оцъ - П 1773), што потврђују и примери из контролног корпуса (светљејшега господина владике - У 1725; Предражајши мој господине - П 1725; Преподобњејши и словесњејши господине оче игумане 1747; и сл.).

У стилски немаркираним контекстима форме компаратива и суперлатива су народне: ... за-Фнога с-коием-би било болъ... (ПИ 1750); наипосльдну (1757). ${ }^{19}$

\section{4. Личне заменицุе}

У највећем броју потврда форме личних заменица јесу народне: итако-су Фни мене дозвали (ПИ 1749); у-писму мени ниесу донїели нища (ПИ 1749); мећу нама (ПИ 1749); да-цюи-се има наћи начин (О 1751); Молећи мене (1757); за нега (1757); Како-е мила вама ваша Корисъ тако-е и нама мило (ПИ 1749); за-нега (ПИ 1750).

\footnotetext{
18 Оваква ситуација забележена је и у језику једног писма из 1728. из Зубаца (Младеновић, 1977: 280).

19 На сличан однос у употреби компаративних и суперлативних форми указују и истраживања језика владике Данила (Младеновић, 1973: 151-152).
} 
Забележена је и употреба енклитичке форме 2. лица множине у дативу ви: що сте у-ваше руке примили, що-сам-ви А у-руке даш (ПИ 1749); зато-самви и-препоручїळ (ПИ 1749); и др. ${ }^{20}$

Књишки облици (в. Ремнёва и др., 1999: 48) регистровани су у двама примерима: ва-коемъ извъстно разумъсмо васа чертана^ в-немъ (ПИ 1750); и міръ хртовъ буди с-вамі (ПИ 1750).

\section{5. Глаголи}

3.5.1. Инфинитив. У грађи су посведочене форме и крњег и инфинитива на -mu: ${ }^{21}$...а-речене цекине даму-и имамъ лиепо вратити (У 1714, 1. 9); не-умиући онъ писатъ (У 1714, 1. 9); и-свакъ-е Контен да-би могло то бить и свакъ шбећава да-ће дати за-спензе ... (ПИ 1749); хоће-ли Принципъ допустить (ПИ 1749); ...да-ће Принципь допущить (ПИ 1749); ${ }^{22}$ изићи (ПИ 1749); доћи (ПИ 1749); доћъ (ПИ 1749); возити (ПИ 1750); да-би [...] могаюПристать (ПИ 1750), да-море имать свою крьпость (П 1778); и др. ${ }^{23}$

3.5.2. Презент. У анализираној грађи готово се доследно употребљава наставак -м у 1. л. једнине презента: некасе зна п-о-воме писму али-ти шкриту како узе иа петко терзић савине у господина проигумна гаврила калућера савине на-бутигу цекина 35 велу тридесет-и и-петь за-коему даемъ у реумъ мои виноград (У 1714, 1. 9); ...а-речене цекине да-му-и имамъ лиепо вратити (У 1714, 1. 9); изповиедам іа подписани како примих... (П 1747, 3. 6); вратим (П 1747, 3. 6); не-знамъ (ПИ 1749); нарећуием и препоручуием (О 1751); упишем (1757), Фчитуемъ (П 1778); и др.

Само је у једном случају забележена књишка форма (в. Ремнёва и др., 1999: 72), при чему треба нагласити да је реч о есхатоколу: При-сем-же

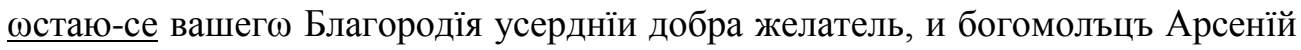
Игуменъ (ПИ 1750).

\footnotetext{
${ }^{20}$ Иста ситуација забележена је и у језику владике Данила (Младеновић, 1973: 140) и источне Херцеговине (Пецо, 1964: 132). У језику Каменара среће се употреба паралелних форми вам/ви и сл. (Вујадиновић, 2007: 84).

${ }^{21}$ Иста ситуација регистрована је и у говорима источне Херцеговине (Пецо, 1964: 159).

${ }^{22}$ Аналошко ширење групе $и т$, добијене јотовањем, забележено је и у језику владике Данила (Младеновић, 1973: 163).

${ }^{23}$ У језику владике Данила, као и у савременим говорима Каменара доминантније су краће форме (Младеновић, 1973: 88; Вујадиновић, 2007: 88-89).
} 
Форма вељу, типична за говоре источне Херцеговине (Пецо, 1964: 149) и Каменара (Вујадиновић, 2007: 91), такође је регистрована у грађи: нека-се зна п-о-воме писму али-ти шкриту како узе иа петко терзићъ савине у господина проигумна гаврила калућера савине на-бутигу цекина 35 велу тридесет-и и-петъ... (У 1714); велу (П 1747); и др.

У 3. л. једнине и множине чувају се народни наставци: ...що се-наоди на ћурћеву брду (У 1704, 12. 8); све що се ниово назива (П 1709, 14. 10); ... како говори горне писмо (П 1714, 1. 9); добро да-сезна... (П 1715); Много времена има... (ПИ 1749); ... што изискава... (ПИ 1749); и свакъ юбећава да... (ПИ 1749); та-не-дава нико нища (ПИ 1749); истина-е да-сте Писали Свїетлому геуу Капетанъ Вуковою и-неговїемъ Сућамъ, вашиемъ Колегамъ, да-поћу у-задаръ ... (ПИ 1749); да-не-море ова Стваръ изићи (ПИ 1749); не-бих радъ [...] да-ми реку ${ }^{24}$ Братїя (ПИ 1749); морете $^{25}$ (ПИ 1749, 1750); ...да-ми буду на помоћи (О 1751); да имаду уживати (1751); да имаиу исте двие речене уживати (О 1751); заповїеда, одлучуе и нарећуе (1757); на-кое се дава $(1757){ }^{26}$ приме (1757); исповиеда (П 1763); да имаду (О 1775); ужива-се (О 1775); давасе (О 1775); како-се види у либру (П 1778); да-море имать свою крьпость (П 1778); держи (П 1779).

Књишке форме (в. Ремнёва и др., 1999: 72-73) регистроване су само на једном месту, у тексту из 1778: ...да-му-се На-сваку Годину, На-пресвњтои Служби Божїеи, Сарандарима Поминаютъ, имена, коя-се иментуютъ у-овому писму (П 1778).

У 1. л. множине доследно су регистровани народни наставци: залагамо (У 1704); ...данима-се помагамо (У 1704); не-познавамо (ПИ 1750); ${ }^{27}$... У-коем

\footnotetext{
24 Ова је форма, поред речу, рекну, такође потврђена у говору источне Херцеговине (Пецо, 1964: 159), али не и у Каменарима (Вујадиновић, 2007: 91).

25 Поред форми са ж у основи, у говорима источне Херцеговине такође се употребљава форма морем и сл. (Пецо, 1964: 15).

26 Задржавање инфинитивне основе и у презенту код глагола на -ава- забележено је и у језику писама владике Данила (Младеновић, 1973: 161).

27 Одсуство јотовања у презенту и његово грађење од инфинитивне основе код глагола помагати забележено је и у језику писама владике Данила (Младеновић, 1973: 162), а у говорима источне Херцеговине и Каменара то је уобичајена појава за глаголе на -авати (Пецо, 1964: 150; Вујадиновић, 2007: 91).
} 
Сердачно жудимо щоби Премилостиви богъ дає... (ПИ 1750); не-хоћемо (ПИ 1750); بинимо (П 1773); ㅆіимамо (П 1778). ${ }^{28}$

3.5.3. Футур I и II. Футур I гради се доследно од енклитичких облика помоћног глагола хтети у презенту и инфинитива: ... ће бити иоще подтписато... (П 1715); и свакъ Фбећава даћедати за-спензе ... (ПИ 1749); ...коиа-ће-ми сачувати моиу душу (О 1751); бити-ће подписато (О 1751); биће ово писмо подписато (1757); бити-ћеподписато су-два сиедока коием будем рећи ... (О 1751).

У анализираној грађи забележена је конструкција са глаголом бити у презенту и инфинитивом, у значењу футура 2: битиће подписато судва сиедока коием будем рећи ... да му буде виеровато (О 1751); ... кад-се-буде згодити нъгова смертъ да се нъгово тьло погребе... (1757); ...кое-се будеть служити свагда (П 1778). ${ }^{29}$

3.5.4. Перфекат. Гради се искључиво са помоћним глаголом и партиципом претерита: ... що-нам е узеш (У 1704, 12. 8); що сте у-ваше руке примили (ПИ 1749); Много времена има да нїесамъ-Примию вашего Писанїя, ниавиза никаква... (ПИ 1749); е имао (1757); примихъ иа [...] дуката биелие 20 що-нам-и-еоставио покоини стрицъ ... (П 1715); како-е примиє у-частние отаца (П 1763); кои-се преставїо (П 1778); и др. ${ }^{30}$

3.5.5. Аорист. Посведочени примери указују на доследну употребу народних наставака у аористу: синови кнеза драгутина даше ћурћево брдо (П 1709); дасмо за цекина 40 (П 1709); даде ми више (У 1714). ${ }^{31}$

\section{4. ЗАКЉУЧАК}

Анализирани текстови указују на доминантну употребу народног језика све до средине 18. века, уз ретке црте из вишег стила (попут форми суперлатива, потврђених само у контролном корпусу). Тек од 1749. г. у појединим документима уочавају се приметнији књишки наноси и везују се за образовања у оквиру синтагми које реферишу о религиозном контексту, о представницима високе црквене хијерархије, о угледним званичницима, о

\footnotetext{
${ }^{28}$ На сличну ситуацију у погледу грађења презента указују и истраживања језика владике Данила (Младеновић, 1973: 153).

${ }^{29}$ Наведена конструкција, поред форме презента са префиксом уз-, забележена је и у језику владике Данила (Младеновић, 1973: 158-159).

${ }^{30}$ На исту ситуацију указује и језик владике Данила (Младеновић, 1973: 159).

${ }^{31}$ Иста је ситуација и у језику владике Данила (Младеновић, 1973: 154).
} 
устаљеној етикецији и формулацијама у есхатоколу писама. Будући да је у питању морфолошки ниво, у највећем броју случајева немогуће је идентификовати редакцију (српску или руску). Ретки примери ипак указују на рускословенски језик (и за помоћь Новїя Церкве; П 1778), а такву ситуацију потврђују и ранија истраживања фонолошког система, реализована на истој грађи (в. Бјелаковић, 2018).

Поједини регионализми, типични за савремене говоре овог краја, регистровани су и у анализираним текстовима (нпр. уопштавање наставака из некадашње тврде заменичке промене у инструменталу једнине, генитиву, дативу, инструменталу и локативу множине придевско-заменичке промене; употреба форми вељу, морем; хипокористици на -о; уопштавање инфинитивне основе у презенту код појединих глагола).

Иако анализа фонолошке структуре истих докумената (в. Бјелаковић, 2018) указује на сличну ситуацију у погледу појаве рускословенских црта, те зависности употребе књишких форми од социјалне стратификације учесника у кореспонденцији, као и тематике појединих домена докумената - тек ће наредна исцрпнија истраживања пословно-правних текстова Срба 18. века у потпуности осветлити питања језика у њима.

Isidora G. Bjelaković

NOTES ON THE MORPHOLOGICAL STRUCTURE OF THE DOCUMENTS IN THE ARCHIVE OF THE SAVINA MANASTERY $\left(18^{\text {th }}\right.$ CENTURY $)$

\section{Summary}

This paper analyzes the morphological structure in the language of documents stored in the Archive of the Savina Monastery, which date back to the eighteenth century and were written either at the monastery or in its surroundings. The study was conducted in order to observe when they were penetrated by Russian Church Slavonic morphological characteristics. Particular attention is paid to individual, regional features typical of Northwest Boka and the wider region of eastern Herzegovina.

The analysis indicates that the influence of Russian Church Slavonic as well as the preservation of Serbian Church Slavonic morphological characteristics began in the mideighteenth century. It seems it was conditioned by the social status of the participants in the correspondences as well as by the thematic areas in a particular text. Some regionalisms that were typical of contemporary speech in this region were also recorded in these texts.

Key words: archive of Savina Monastery, 18th century, Serbian language, morphology. 
Албин, А. (1968). Језик новина Стефана Новаковића (1792-1794). Нови Сад: Матица српска.

Бјелаковић, И. (2018). Напомене о фонолошкој структури докумената Архива манастира Савина (18. век). Доситејев врт, VI/6, У штампи.

Вујадиновић, Н. (2007). Говор Каменара. Београд: Научно друштво за неговање и проучавање српског језика. Серија IV. Број 4.

Јерковић, Ј. (1972). Језик Јакова Игњатовића. Нови Сад: Матица српска.

Јерковић, J. (1976). Језик Богобоја Атанаџковића. Нови Сад: Матица српска.

Кашић, J. (1968). Језик Милована Видаковића. Нови Сад: Матица српска.

Комар, Г. Ж. (2009). Бока Которска. Ћирилски споменици 17. 18. и 19. вијека (ActaSerbica). Мјешовита грађа (1608-1917). Архив града ХерцегНовог, Архив манастира Савине, Приватне збирке Боке, Херцег-Нови.

Милановић, А. (2014). Језик Јована Суботића. Београд: Филолошки факултет.

Младеновић, А. (1964). О народном језику Јована Рајића. Нови Сад: Матица српска.

Младеновић, А. (1969). Однос између домаћих и рускословенских елемената у књижевном језику код Срба пре његове Вуковске стандардизације. Зборник Матице српске за филологију и лингвистику, XII, 43-53.

Младеновић, А. (1972). Језик трију цеклинских писама из друге половине 18. вијека. Зборник за језик и књижевност, 1, 45-58.

Младеновић, А. (1973). Језик владике Данила. Нови Сад: Матица српска, 1973.

Младеновић, А. (1977). Филолошки коментар уз једно писмо из Херцеговине упућено Дубровнику 1728. године. Akademija nauka i umjetnosti Bosne $i$ Hercegovine. Posebna izdanja. Knjiga XXXIV. Odeljenje društvenih nauka. Sarajevo. Knjiga 6, 273-283.

Младеновић, А. (1987). Карактер језика неких писама будимског епископа и карловачког митрополита Вићентија Поповића из првих деценија XVIII века. Сентандрејски зборник, 1, 225-236.

Младеновић, А. (1992). Језик трију сентандрејских писама из првих деценија XVIII века. Сентандрејски зборник, 2, 137-148.

Нуорлуото, Ј. (2017). Језик Јована Стејића. Допринос историји стандардног језика код Срба, Едиција Студије о Србима. Београд - Нови Сад: Вукова задужбина - Завод за уџбенике - Матица српска.

Пецо, А. (1964). Говор источне Хериеговине. Српски дијалектолошки зборник. Књига XIV. Београд: Институт за српскохрватски језик, 1-200. 
Ремнёва, М. Л. и др. (1999). Церковнославянский язык. Москва: Издательство Московского университета.

Стојановић, J. (2011a). Континуанти старог полугласника у Паштровским исправама. Научни састанак слависта у Вукове дане, 40/1, 263-278.

Стојановић, J. (2011б). Морфолошке карактеристике генитива и локатива множине у Паштровским исправама: 16-19. вијек. Српски језик, књижевност, уметност: зборник радова са V међународног научног скупа. Књижевни (стандардни) језик и језик књижевности. Крагујевац. Књига 1, 371-385.

Стојановић, J. (2012). Употреба предлошкопадежних конструкција с акузативом - локативом и инструменталом у значењу просторних односа у Паштровским исправама (16-19. вијек). Пале: Филозофски факултет. Наука и идентитет: филолошке науке. М. Ковачевић (ур.), 229-244.

Суботић, Љ. (1989). Језик Јована Хаиића. Нови Сад: Матица српска.

Суботић, Љ. (2004). Из историје књижевног језика: „питање језика”. Предавања из историје језика. Нови Сад: Филозофски факултет, $142-$ 191.

Херити, П. (1983). Къижевни језик Емануила Јанковића. Нови Сад: Матица српска.

Kuna, H. (1970). Jezičke karakteristike književnih dela Dositeja Obradovića. Sarajevo: Akademija nauka i umjetnosti Bosne i Hercegovine, Odjeljenje istorijsko-filoloških nauka. Knjiga 21. Djela XXXVI. 